\title{
Letter to the Editor RE: Modification of oxytocin use through a coaching-based intervention based on the WHO Safe Childbirth Checklist in Uttar Pradesh, India: a secondary analysis of a cluster randomized controlled trial
}

Avir Sarkar ${ }^{1}$, Shalini Venkatappa ${ }^{1}$, and Isha Wadhawan ${ }^{2}$

${ }^{1}$ Post Graduate Institute of Medical Education and Research

${ }^{2}$ Fortis Escorts Hospital Jaipur

September 24, 2021

Letter to the Editor RE: Modification of oxytocin use through a coaching-based intervention based on the WHO Safe Childbirth Checklist in Uttar Pradesh, India: a secondary analysis of a cluster randomized controlled trial

Avir Sarkar, $\mathrm{MD}^{1}$; Shalini Venkatappa, $\mathrm{MD}^{1}$; Isha Wadhawan, MD, Diplomate to $\mathrm{ABOG}^{2}$

1 - Department of Obstetrics and Gynecology, Post Graduate Institute of Medical Education and Research (PGIMER), Chandigarh, India

2 - Department of Obstetrics and Gynecology, Fortis Escorts Hospital, Faridabad, Haryana, India

Corresponding author: Avir Sarkar

Address: House number 12, Block F, NIT-3, Faridabad, Haryana-121001, India

E mail: avirsarkar93@gmail.com

Type of article: Letter to the Editor

Word count: 464

Number of references: 2

Conflict of interest between authors: None declared

Hosted file

Letter to the Editor, BJOG 2.docx available at https://authorea.com/users/435554/articles/ 538492-letter-to-the-editor-re-modification-of-oxytocin-use-through-a-coaching-basedintervention-based-on-the-who-safe-childbirth-checklist-in-uttar-pradesh-india-asecondary-analysis-of-a-cluster-randomized-controlled-trial 